\title{
IGÉNYVEZÉRELT RAKTÁROZÁSI RENDSZEREK OPTIMÁLIS ANYAGMOZGATÁSI STRATÉGIÁJÁNAK KIVÁLASZTÁSÁRA SZOLGÁLÓ RENDSZER MÜKÖDÉSI KONCEPCIÓJÁNAK KÖLTSÉGMODELLJE
}

\author{
Dobos Péter \\ Miskolci Egyetem, Logisztikai Intézet \\ 3515 Miskolc, Miskolc-Egyetemváros, e-mail: peterdobos30@gmail.com.hu \\ Illés Béla \\ egyetemi tanár, Miskolci Egyetem, Logisztikai Intézet \\ 3515 Miskolc, Miskolc-Egyetemváros, e-mail: altilles@uni-miskolc.hu \\ Tamás Péter \\ intézetigazgató egyetemi docens, Miskolci Egyetem, Logisztikai Intézet \\ 3515 Miskolc, Miskolc-Egyetemváros, e-mail: tamas.peter@uni-miskolc.hu
}

\begin{abstract}
Absztrakt
Az ipari szereplők, vállatok számára egyre nagyobb kockázatot jelent a piac hektikussága és a végfelhasználók keresletének nehéz és csak rövidtávú tervezhetösége. A legtöbb ipari szereplö a fentarthatóság érdekében alkalmazkodik az új piaci környezethez és ezen alkalmazkodás a rendelkezésre álló pénzügyi keretek átcsoportositásaival, kiadások jelentés csökkentésével, megszoritásokkal, és végső soron átszervezésekkel jár. Jelentös segitség a vállalatok számára minden olyan módszer vagy eljárás, ami segít a rendelkezésre álló adatok alapján a várható költségek meghatározásában és tervezésében. A kidolgozott eljárás alkalmazható termelö vállatok számára a költségre optimalizált raktározási stratégia kiválasztására, figyelembe véve az üzleti tervben szereplö lekötött töke értékét és beruházási lehetöségeit. Tervezhetöséget és kiszámithatóságot biztositva a felmerülö költségek területén.
\end{abstract}

Kulcsszavak: Raktározási rendszerek, igényvezérlés, tervezés

\begin{abstract}
The hectic nature of the market and the difficult and only short-term planning of end-user demand pose are an increasing risk to industrial actors and companies. Most industrial participants are adapting to the new market environment for sustainability, and this adaptation involves reallocations of available financial frameworks, reductions in expenditure reporting, austerity, and ultimately restructuring. Any method or procedure that helps to determine and plan the expected costs based on the available data is a significant help to the companies. The developed procedure can be applied to production companies to select a cost-optimized warehousing strategy, taking into account the value of the committed capital and investment opportunities included in the business plan. Providing predictability and predictability in terms of costs incurred.
\end{abstract}

Keywords: Warehousing systems, demand control, planning 


\section{Bevezetés}

Az igényvezérlés fogalmának meghatározása egy termelő és raktározási tevékenységet folytató multinacionális vállalat estén nem egyértelmü. Egy vállalat fentarthatósága szempontjából az elsődleges ,igény” a folyamatos pozitív EBIT (earnings before interest and taxes) elérése és ennek érdekében a költségek tartós és drasztikus csökkentése [1]. Az autóipari végfelhasználók igénye nem ismert és a termelő vállalatok a szigorodó környezetvédelmi normákra rövid távú, nem kiszámítható stratégiákkal készülnek.

A gyakorlati életben a költségek csökkentésének egyik formája a veszteségek azonosítása és eliminálása. Ez a törekvés leginkább a termelési területekre korlátozódott csekély mértékben figyelembe véve a kapcsolódó raktározási rendszerek müködését és szinergikus összekapcsolódását a termelési anyagáramlással. Raktározási területen a problémák alapvetően abból adódnak, hogy az alapanyag, valamint a késztermék raktározás esetén az input és output anyagáramok jelentős mértékben, sok esetben sztochasztikusan ingadoznak, így a készletezési mechanizmusok csak jelentős pontatlansággal határozhatók meg. A folyamatosan változó vevői igények okozta pontatlan készletgazdálkodás jelentős hatást gyakorol a gyártandó termékek alapanyagainak előkészítésére, a termék gyártási átfutási idejére és tervezhetőségére és ez által a megrendelői igények időben történő kiszolgálására. A hektikusan ingadozó vevői igények előrejelzései által generált beérkező anyagok betárolása és meglévő készletekbe történő beintegrálása, lokációjának optimalizálása, a gyártás után visszaáramló anyagok visszatárolása és a gyár termékportfóliójának gyártandó mennyiségalapú priorizált előkészítési időcsökkentő anyag kitárolása egyszerü, minden változót figyelembe vevő algoritmussal nem lekövethető [2;3]. Ezen folyamatok együttese fokozott készletnövelő hatást gyakorol az egy időpillanatban meglévő raktárkészletre. Másrészről a különböző raktározási intenzitásokhoz tartozó emberi és gépi erőforrások kapacitásának optimalizált meghatározásával, müködtetésével kapcsolatban nincsenek kellő részletezettséggel kidolgozva az alkalmazandó módszerek, eljárások [4]. Az előzőekben ismertetett problémákon túl jelentős hiányosságként jelentkezik, hogy a raktározási rendszerek müködtetésének felülvizsgálata nem, vagy csak hosszabb időszakonként történik meg, melyek következményeként sok esetben nem kerül sor a szezonális hatások miatt szükségessé vált változtatások érvényesítésére [5].

A termelő vállalatok napi operatív irányítása mellett a jövőre irányuló közép és hosszú távú stratégia tervezése létfontosságú folyamat. A stratégia meghatározásának alapja egy olyan keretfeltétekkel rendelkező környezet kell, amely a változó paraméterektől függően, azonos bázisra és dimenziókra vonatkoztatott összehasonlítható javaslatokat képes elöállítani. Ezen adatok szolgálnak a közép és hosszú távú stratégia által igényelt esetleges beruházások megtérülő, időbeni tervezhetőségéhez. A termelő vállatok számára az alapanyag gazdálkodás, készletlekötés szerves része a stratégiaalkotásnak, amelynek megalapozásához szükséges az optimális anyagmozgatási stratégia meghatározása.

A kidolgozott módszer vázát a gyártási területek igényeinek kiszolgálását biztosító jól ismert be- és kitárolási stratégiák összehasonlíthatósága adja. Az értékáramon belüli anyagmozgatási lépések mindegyikében kiértékelésre kerül a be- és kitárolási stratégiák költség hatása. Ez által számos alternatíva vizsgálata válik lehetővé. A matematikai modell az anyagmozgatási útra vetített fix és változó költségek minimalizálása mellett javaslatot ad az optimális anyagmozgatási stratégia kiválasztására.

Egy anyagmozgató rendszer modellje a Miskolci Egyetem Logisztikai Intézetének laboratóriumában található [7], amelynek része egy AGV [8]. 


\section{Vizsgálati lehetőségek ismertetésé}

A kidolgozott módszer lehetővé teszi a teljes értékáramot átfogó optimális anyagmozgatási stratégia kiválasztását. Az értékteremtési folyamatok három nagyobb részre tagozódnak,

- alapanyag beérkezés és tárolás,

- gyártási terület alapanyag kiszolgálása és anyag gazdálkodása,

- késztermék tárolás és kiszállítása.

A gyártási területek magas négyzetméter költsége miatt a gyártó berendezések üzemeltetése az elsődleges cél az üzemi területeken és az alapanyag, félkész és késztermék készleteinek minimalizálása mellett.

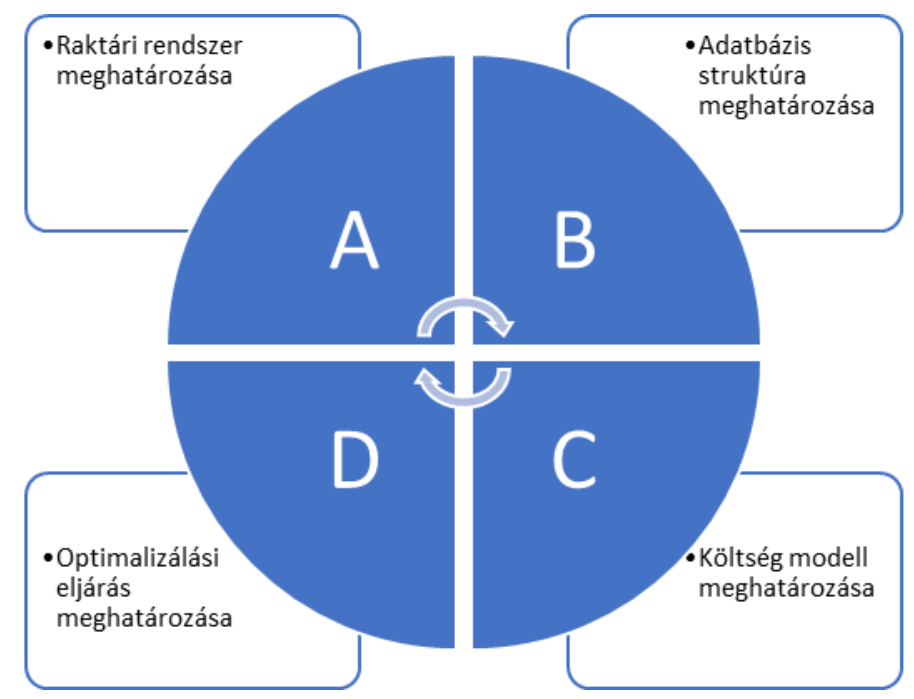

1. ábra. Kidolgozott modell föbb részei [saját szerkesztés]

Annak érdekében, hogy a gyártás folyamatos alapanyag ellátottsága biztosított legyen, figyelembe kell venni a gyártási berendezések és folyamatok kiszolgálási igényeit. Ezen igények jelentős befolyást gyakorolnak az alapanyag betárolásának, készletezésének és a késztermék készletezésének, kitárolásának folyamataira.

Az 1. ábrán bemutatott modell négy fő részre tagolható, amelyek egymásra épülve alkotnak egy egész rendszert, biztosítva az optimumkereséshez szükséges legfontosabb bementi adatokat és eljárásokat.

- A raktári rendszer meghatározása

- Adatbázis struktúra meghatározása

- Költség modell meghatározása

- Optimalizálási eljárás meghatározása

A raktári rendszer felépítésének és paramétereinek meghatározása, a szükséges adatstruktúrák létrehozása szolgáltat alapot a költség modell számára, aminek kimeneti adatai kerülnek kiértékelésre az optimalizálás során.

A kidolgozott módszer vázát a gyártási területek igényeinek kiszolgálását biztosító jól ismert be- és kitárolási stratégiák összehasonlíthatósága adja. Az értékáramon belüli anyagmozgatási lépések 
mindegyikében kiértékelésre kerül a be- és kitárolási stratégiák költség hatása. Ez által számos alternatíva vizsgálata válik lehetővé. A matematikai modell az anyagmozgatási útra vetített fix és változó költségek minimalizálása mellett javaslatot ad az optimális anyagmozgatási stratégia kiválasztására.

\section{Raktári anyagmozgatási stratégia kiválasztását végző rendszer működési mechanizmusa}

A vizsgálati modell tömbösített formája a 2. ábrán látható. A modell középpontjában az anyagmozgatási stratégia optimális megválasztását végző modul helyezkedik el. Az optimalizáló modul minden anyagmozgatási lépésnél megvizsgálja a be- és kitárolási stratégia által elérhető költséget. Minden be- és kitárolási lépéshez hozzárendelhetőek a be- és kitárolási stratégiák.

Az anyagok betárolási folyamata történhet: véletlen betárolási, legközelebbi nyitott tárhelyre történő betárolási, fix tárhelyes betárolási, osztály szerinti betárolási stratégia szerint.

Az anyagok kitárolási folyamata történhet: FIFO, LIFO, FEFO, LEFO, HIPO stratégia szerint.

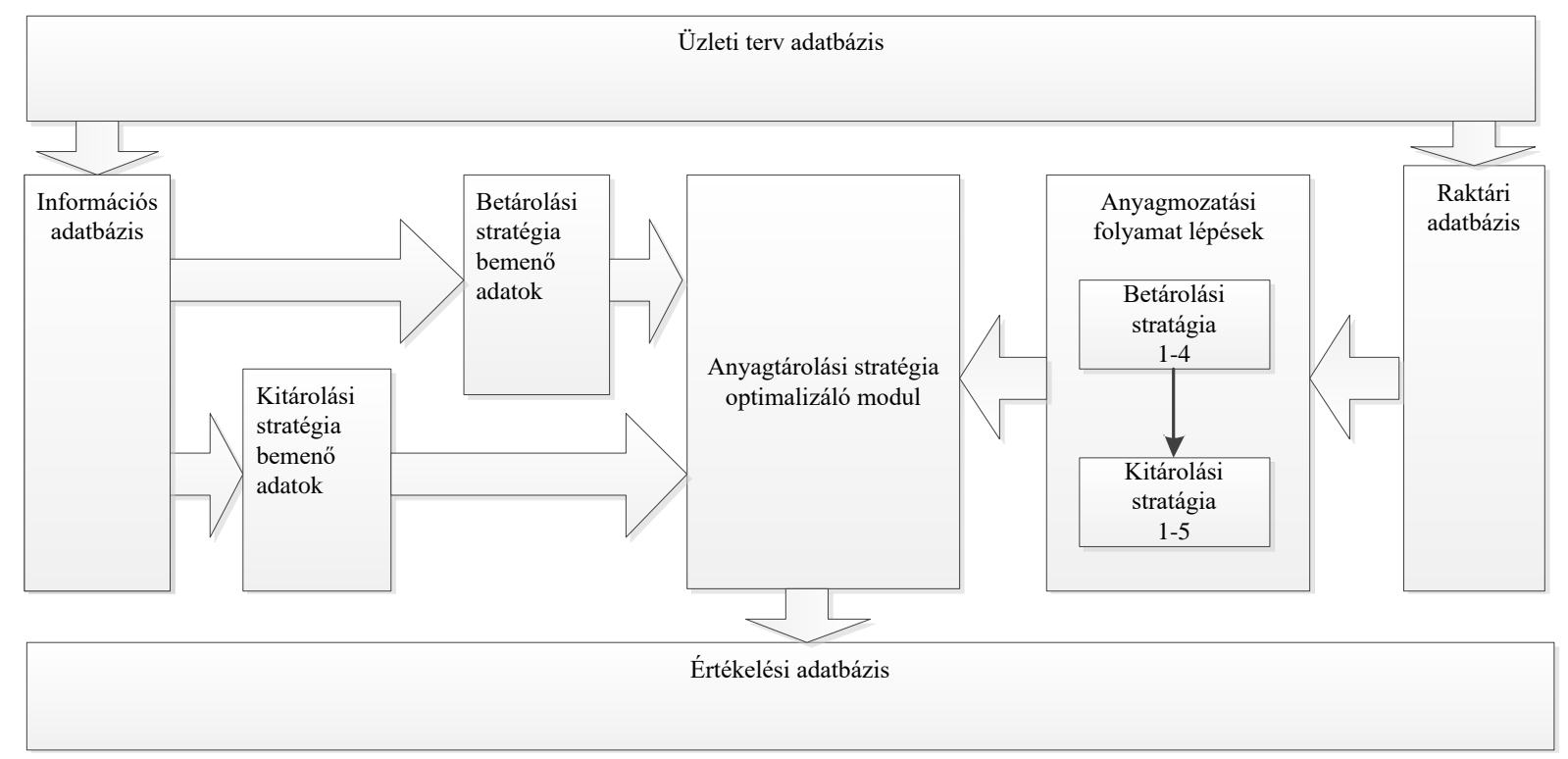

2. ábra Optimális vizsgálati modell tömbösített formája [saját szerkesztés]

Az optimális raktári anyagmozgatási stratégiaváltozat kiválasztása egy szimulációs vizsgálati módszer segítségével kerül megvalósításra, amely egy kijelölt múltbeli időszak és egy elöre tervezett időszak adatainak felhasználásával „szimulálja” a különböző stratégiaváltozatok szerinti anyagáramlási-rendszer müködését, majd a stratégiaváltozatonként kapott logisztikai mutatók értékei alapján a legkedvezőbb célfüggvény értékkel rendelkező változat kerül kiválasztásra. A folyamat lépéseit a 3. ábra szemlélteti [6]. 


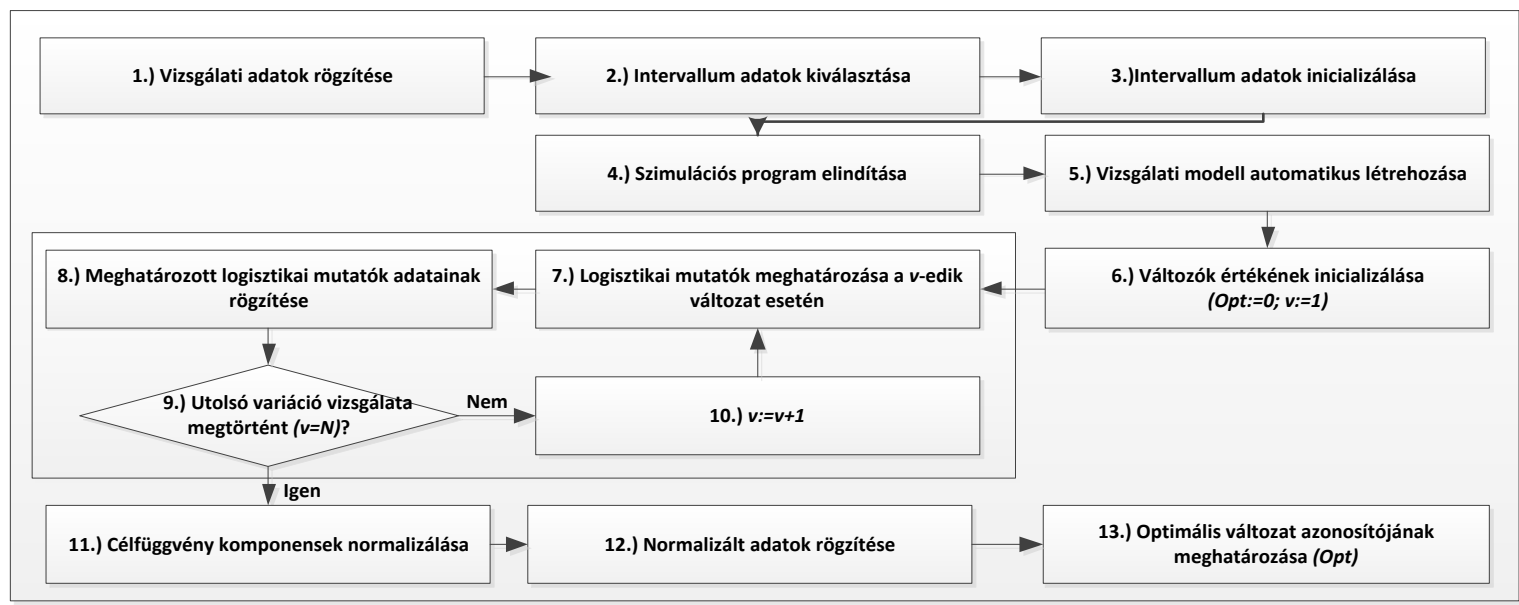

3. ábra Igényvezérelt optimális anyagmozgatási stratégia kiválasztásának koncepciója [saját szerkesztés]

Az optimális anyagmozgatási stratégia kiválasztását végző rendszer adatstruktúrájának modelljét a 4. ábra szemlélteti.

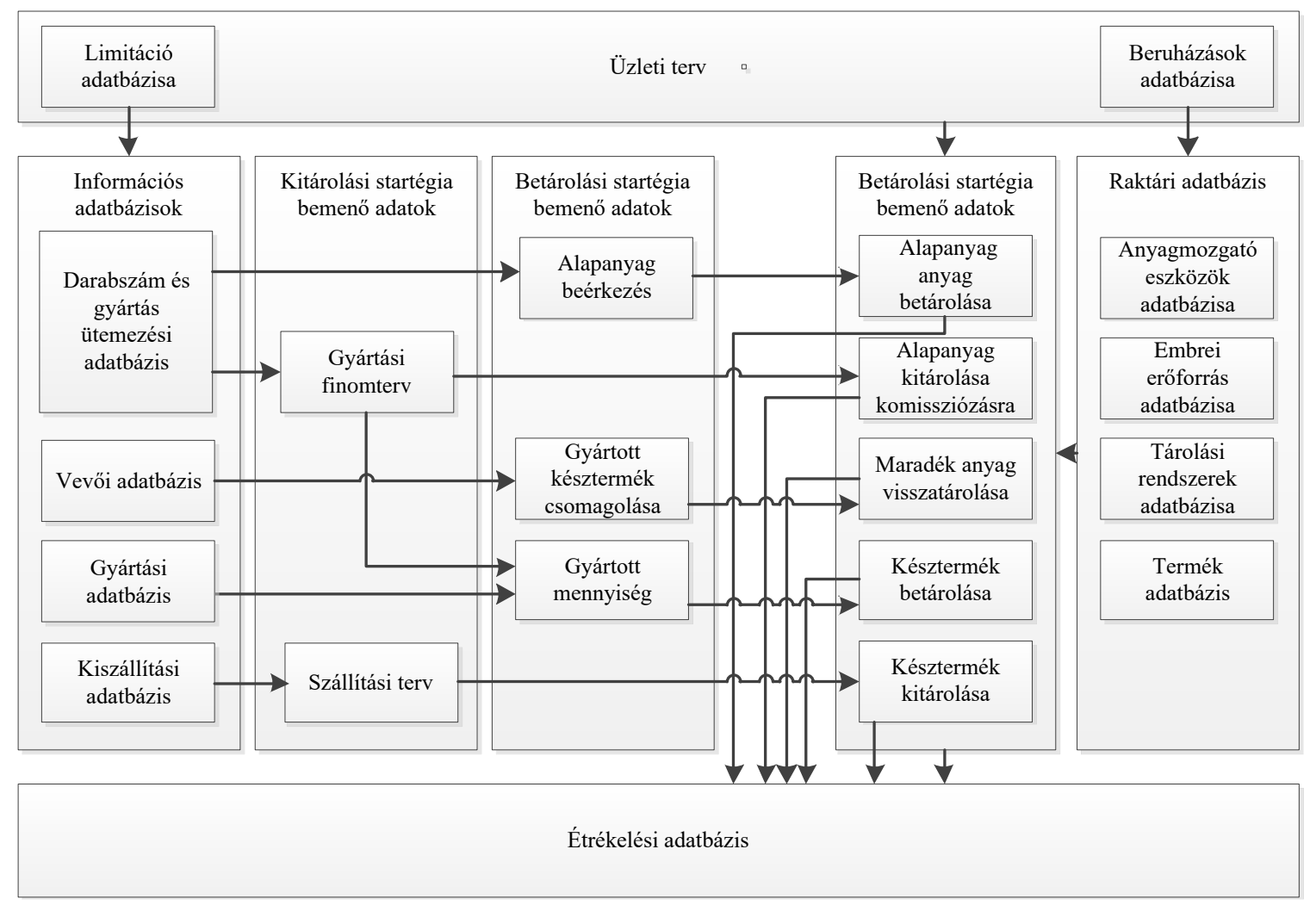

4. ábra Optimális anyagmozgatási stratégia kiválasztását végző rendszer adatstruktúrája [saját szerkesztés] 
Az üzleti terv mutatja meg egy cég fökönyvi eredményét a tervezett forgalmi érték és a kiadások figyelembevételével. A kiadások közé tartozik a raktári adatbázisok elemeinek finanszírozása, amely megmutatja, hogy milyen maximális beruházás, lekötött tőke és értékteremtő műveletek mellet érhető el a legnagyobb üzleti eredmény.

Az információs adatbázis határozza meg az igényeket a raktári folyamatok felé. Az adatbázis szoros összefüggésben van az üzleti tervezéssel és az operatív gyártásirányítási folyamatok tervezésével.

A vevő megrendelések előrejelzése határozza meg a gyártandó termék palettáját és mutat eloszlást az igények változásában a naptári éven belül. Ezen előrejelzés feldolgozása és ütemezése „igényt” generál az alapanyag rendelésre és a beszállítóktól érkező visszajelzések után pedig az alapanyag beérkezésére. A beérkezés ütemezése szolgál információval - bemeneti adatként -, hogy a logisztikai folyamatoknak, hogy milyen anyag beérkezését kell kezelni. A visszaigazolt beérkezési időpontok simítása további lehetőséget nyújt az optimalizáció folyamatában, de a későbbi modell erre a nem tér ki.

A készletezett alapanyag felhasználása a gyártás számára a vevői megrendelések gyártásba ütemezésével történik, aminek alapja a megrendelés teljesítésének időpontja. A termék vevő részére történő leszállítási időpontja, a szállítási cím távolsága a gyártási telephelytől, a készleten lévő már gyártott termékek darabszáma és a gyártási átfutási idő határozza meg, hogy mikor kerüljön a termék a gyártásba. A gyártási finomterv elkészítése tovább optimalizálható „pull”-rendszeren (húzó rendszer) keresztül és simított gyártással kombinálva, ami a logisztikai folyamatok ütemezhetőségére is pozitív hatással van, de erre az optimalizációs lehetőségre a modell nem tér ki.

A legyártott termékek a vevők kérése szerint különbözőképpen kerülnek csomagolásra. A vevői csomagolásba elhelyezhető késztermékek darabszáma és az alapanyagok csomagolási egységenkénti darabszáma az esetek nagy részében eltér, ezért a gyártási tervben szereplő késztermék mennyiség legyártása után a maradék alapanyag visszatárolásra kerül a raktárba. Ennek célja, hogy elkerüljük a túlgyártást és az alapanyag felhasználását más gyártandó késztermékek elől.

\section{Igényvezérelt raktározási rendszer kiválasztását és müködtetését támogató költségmodell}

Az optimális raktári anyagmozgatási stratégia kiválasztásához a vizsgálat során felvázolt alternatív lehetőségek összehasonlításának egyik legfontosabb mutatója a költség. A raktározási stratégia kiválasztásánál cél a lehető legkisebb költséggel történő üzemeltetés, ami a teljes raktározási folyamatban fellelhető kiadásokat jelenti.

A raktárhoz kapcsolódó költségek 2 részre bonthatóak az alábbiak szerint.

1. Változó költség: Minden olyan költségelem, ami a raktári terhelésben - kezelt termékek számában - bekövetkezett változás esetén változik. A következő költségek sorolhatók ebbe a kategóriába:

- Bérköltségek: A raktárak elsősorban operatív logisztikai feladatait ellátó személyek bére, mely a raktári terhelés függvényében változhat.

- Az üzemeltetetési költségének bizonyos része, hiszen nem folyamatos üzemeltetés mellett a rezsi költségek pl. villamosenergia csökkenthető az üzemen kívüli világítás lekapcsolásával.

- Lízing szerződések esetén a lízingelt eszközök vagy tároló berendezésék száma szintén változtatható. Ennek költség vonzata és lehetséges reakció ideje a szerződésben meghatározott feltételek szerint jelenik meg. 
2. Fix költségek, minden olyan költség elem, ami a raktári terhelésben - mozgatott termékek számában - bekövetkezett változás esetén nem változtatható.

- Üzemeltetési költség bizonyos része, mint például épület fütése, energia ellátása, biztonsági szolgálat fenntartása, hiszen az alap szolgáltatási szintet akkor is fent kell tartani, ha a raktár nem üzemel.

- Az vállalat tulajdonában lévő gépek, berendezések, raktári épület amortizációs költsége.

A költség elemek meghatározásánál mind a változó és mind a fix költségek az inicializálási szinten kerülnek felhasználásra és értéküket a későbbi szimuláció során állandónak tekintem. A cél a terheléstől függő költségek minimalizálása. A logisztikai mutatók segítségével kiszámolható a raktár teljesítőképessége és költség hatékonysága, ami lehetőséget biztosít a beavatkozásra a korábban bemutatott költség elemek változtatására, viszont ebben az esetben a modellt újra le kell futtatni. Költség elemek közötti összefüggést az 5. ábra szemlélteti.

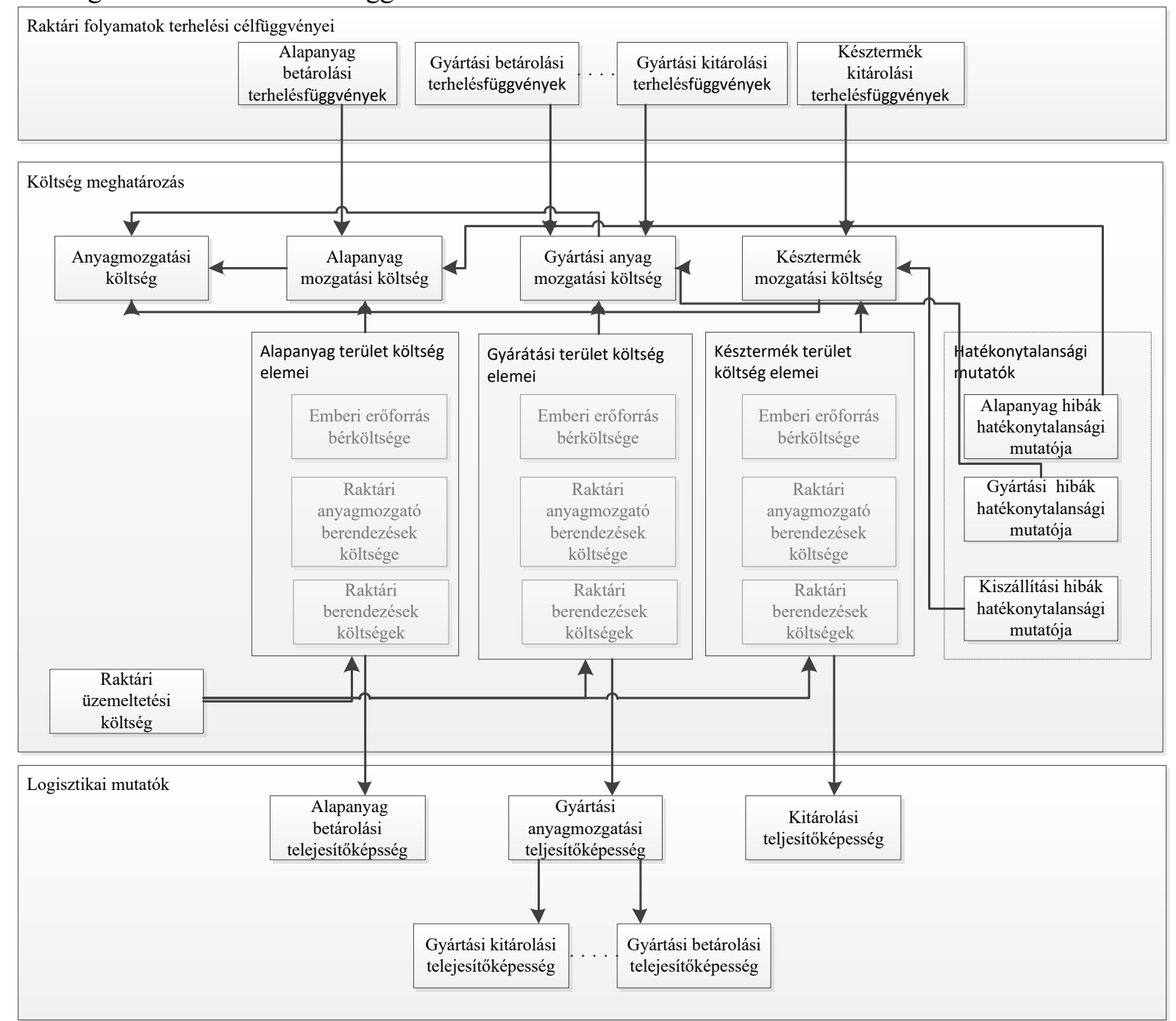

5. ábra Költség elemek és összefüggései [saját szerkesztés] 
A raktározási tevékenységet leíró költségek meghatározásnak lépései a következőkben látható.

1.lépés: Fel kell vázolni a raktár elrendezési modelljét. Meg kell határozni a kiszolgálásban részt vevő gépek számát, berendezések típusát és kapacitását, beérkezés és kiszállítás oldalon a kapuk számát, a segéd területek méretét és raktáron belüli helyét pl. komissiózási terület, visszatárolásra váró gyártási maradék terület, betárolásra váró gyártási késztermék terület. Hozzárendeléseket kell végezni a gépek tevékenységekhez való hozzárendelésében és lehatárolásokat kell tenni az anyag kezelés orientációjában.

2.lépés: Az első pontban meghatározott tétel elemek hozzárendelése a felvázolt raktári elrendezési modellhez. pl. gépek számának hozzárendelése az alapanyag beérkezési oldalhoz. Meg kell határozni az egyes tétel elemek költségét és ennek egy napra vetített fajlagos értékét. Ezen költségek az üzleti tervben szerepelnek ezért csoportok képzése után könnyen megadhatóak.

3.lépés: Raktári folyamatok terhelésfüggvényeinek meghatározása. Ezen terhelésfüggvények segítségével határozható meg az elvégzett raktári folyamatok értékhozzáadó költsége.

4.lépés: A hatékonytalansági mutatók meghatározása hisztorikus adatok alapján figyelembe véve a jövőre irányuló folyamatok hatékonyságát fejlesztő intézkedéseket.

5.lépés: Fajlagos költség függvények meghatározása klaszterezett egységnyi költség, a terhelésfüggvények, és a hatékonytalansági mutatók felhasználásával.

6.lépés: A logisztikai mutatók meghatározása a teljesítménymérés érdekében.

7.lépés: Lekötött tőke készletértékének meghatározása. Az alapanyagban lekötött tőke az egyik legnagyobb veszteségforrás a cég számára, ezért értékének minimalizálására kell törekedni. A készlet minimalizálással párhuzamosan változik az anyagmozgatási költség, hiszen kisebb alapanyag készlet szint gyakoribb, kisebb mennyiségü beszállítást tesz szükségessé, ezért az ideális anyagmozgatási stratégia kiválasztására jelentős hatással bír.

8.lépés: Gazdasági mutatók meghatározása a pénzügyi teljesítmény mérése érdekében.

\section{5. Összefoglalás}

Konklúzióként elmondható, hogy jelentős segítség a vállalatok számára minden olyan módszer vagy eljárás, ami segít a rendelkezésre álló adatok alapján a várható költségek meghatározásában és tervezésében. A megváltozott igényekhez való alkalmazkodás egzakt adatok ás módszer alapján elvégezhető. A kidolgozott eljárás alkalmazható termelő vállatok számára a költségre optimalizált raktározási stratégia kiválasztására, figyelembe véve az üzleti tervben szereplö lekötött tőke értékét és beruházási lehetőségeit.

\section{Köszönetnyilvánítás}

A cikkben ismertetett kutató munka az Erasmus + ProdLog és az EFOP-3.6.1-16-2016-00011 jelü „Fiatalodó és Megújuló Egyetem - Innovatív Tudásváros - a Miskolci Egyetem intelligens szakosodást szolgáló intézményi fejlesztése" projekt részeként - a Széchenyi 2020 keretében - az Európai Unió támogatásával, az Európai Szociális Alap társfinanszírozásával valósul meg.

\section{Irodalom}

[1] Dobos P. Illes B. Tamás P., Conception for selection of adequate warehouse material handling strategy, ADVANCED LOGISTIC SYSTEMS: THEORY AND PRACTICE 2015, 9(1):53-60. 
[2] Marcus Ang,Yun Fong Lim, How to optimize storage classes in a unit-load warehouse, European Journal of Operational Research 2019, 278(1):186-201. https://doi.org/10.1016/j.ejor.2019.03.046

[3] B. Bahrami, H. Piri, and E. H. Aghezzaf, "Class-based storage location assignment: an overview of the literature," in Proceedings of the 16th International Conference on Informatics in Control, Automation and Robotics, Prague, Czech Republic (2019) https://doi.org/10.5220/0007952403900397

[4] Changhong Pan, Shaozheng Yu, Xiaojing Du, Optimization of warehouse layout based on genetic algorithm and simulation technique, 2018 Chinese Control And Decision Conference (CCDC), pp. 3632 - 3635. (2018)

[5] Michael Eder, Analytical model to estimate the performance of shuttle-based storage and retrieval systems with class-based storage policy, The International Journal of Advanced Manufacturing Technology 2020, 107:2091-2106.

https://doi.org/10.1007/s00170-020-04990-y

[6] Dobos P. Illes B. Tamás P, Decision method for optimal selection of warehouse material handling strategies by production companies, IOP CONFERENCE SERIES: MATERIALS SCIENCE AND ENGINEERING 2016, 161:1-7. https://doi.org/10.1088/1757-899X/161/1/012100

[7] Tamás, P., Bányai, T., Illés, B., Tollár, S., Veres, P., Cservenák, Á., Hardai, I., Skapinyecz, R.: Development Possibilities of the High-tech Logistics Laboratory Established at the Institute of Logistics of the University of Miskolc, Journal of Engineering Research and Reports 2020, 13(3):60-68. https://doi.org/10.9734\%2Fjerr\%2F2020\%2Fv13i317127

[8] Cservenák, Á.: Further development of an AGV control system, Lecture Notes in Mechanical Engineering 2018, 376-384. https://doi.org/10.1007\%2F978-3-319-75677-6_32 